\title{
Accountants Perception on Effectiveness of Corporate Fraud Detection and Prevention Methods in Ghana
}

\author{
Kaodui Li \\ School of Finance and Economics, Jiangsu University, China
}

Osei-Assibey Mandella Bonsu (Correspondence author)

School of Finance and Economics, Jiangsu University, China

E-mail: thugdibae1@gmail.com

Kwabena Evans Asare

School of Finance and Economics, Jiangsu University, China

Beraud Jean-Jacques Dominique

School of Finance and Economics, Jiangsu University, China

Boadi Johnson

School of Finance and Economics, Jiangsu University, China

Received: July 19, 2018

doi:10.5296/ijafr.v8i3.13398
Accepted: August 14, 2018

Published: August 20, 2018

URL: https://doi.org/10.5296/ijafr.v8i3.13398

\begin{abstract}
The purpose of the study is to find out the perceptions of Accountants and Auditors on effectiveness of corporate fraud detection and prevention methods among selected financial Institutions in Ghana. The population samples of the study comprising Accountants and Auditors in a selected financial Institutions in Ghana using a structured survey of questionnaires.
\end{abstract}


It was revealed in the study that, organizational quite utilized data mining, digital analysis, internal Control and improvement and fraud prevention and detection training in combating fraud. However, the findings also shows that, organization use of password protection, Cash Review, Annual Auditing, Whistle blowing policy were less often utilized even though having the highest rating of effectiveness. Accountants, Auditors and management of Financial Organizations should considering using the most effective prevention and detection methods like Cash Review, Annual Auditing, whistle blowing and installation of Password protection on computers based on the findings.

The study contributes to the literature on the effectiveness of fraud detection and prevention methods particularly for West African Countries and other emerging nations. The study may be terrific to Practitioners regarding the assessment of the contemporary level of fraud detection and prevention methods on financial Institutions in Ghana and beyond.

Keywords: Fraud, Detection and prevention methods, Accountants, Financial institutions, Ghana

\section{Paper Type: Research Paper}

\section{Introduction}

Corporate fraud schemes go beyond the scope of an employee's stated position, and are marked by their complexity and economic impact on the business, other employees and outside parties (Investopedia, n.d.) Corporate fraud is or are dishonest or illegal activities executed by a company or employees of a company in a manner to give an advantage to the perpetrating company or individual employees of the company. Corporate financial accounting scandals such as ENRON, WorldCom, Global Crossing, Tyco, etc. which have wiped out billions of dollars of shareholders value and led to the erosion of investor confidence in financial markets have increased concerns about fraud. Corporate fraud has colossal detriment on a firm value and as well all sectors of the economy. (Price Waterhouse Coopers (PWC), 2003) as cited by Biers taker et al (2006) shown that globally, the average estimated loss per organization from economic crimes is $\$ 2,199,930$ over a two year period. In the United States of America, the association of certified fraud examiners estimates that about five percent of firm revenues, that is, $\$ 660$ billion per year are lost as a result of occupational fraud. (Association of Certified Fraud Examiners, 2017) The Association of Certified Fraud Examiners in their 2018 report to Nations on occupation fraud shown that Organizations alone lose 5 percent of their annual revenue to fraud amounting to US\$4 billion in losses where applied to 2017 world Gross Product of US\$79.6 trillion. Globally, there has been 140 percent increase in the number of companies reporting financial misrepresentation, a 133 percent increase in the number reporting, money laundering, 71 percent increase in reporting corruption and bribery.(Association of certified fraud examiners(2014). PricewaterhouseCoopers (2011) in their survey revealed that the victims of economic fraud in Malaysia incurred financial losses of between US\$100,000 to US $\$ 5,000,000$ during the particular year. In fact, the organizations also experienced significant collateral damage including damage to employee morale, brand, reputation and business. Corporate fraud can lead to a closure of an organization. The national fraud 
Authority (NFA, 2016) in their recent statistics survey revealed that organizations are engulfed with fraudulent act and is costing the United Kingdom (UK) over £38bn a year. In particular, the financial institutions had the highest loss to fraudsters at cost of $£ 3$.6billion. Corporate fraud has caused losses to numerous entities globally, in cases been reported in Asia-pacific, the Americans, Africa, Russia and Middle East as well in Europe. According to Africa Fraud Barometer, 2014 in their report revealed that, the value of all reported fraud cases in Africa reached \$ 10.8billion. (KPMG, Africa, 2014). The fraud cases hit public sectors and the number has increased from 355 to 520 cases representing 46.47 percent. However, the private sectors fraud cases happen mostly in financial institutions perpetrated by employees in collaboration with clients.

Corporate fraud has gained attention in the Ghanaian business community as its occurrence could have affected it many ways. In the early 2009's, a triggered by Waterville holding Limited bankruptcy after revealing massive accounting fraud of 50million Euros, there was a wave of corporate fraud exposure including Isofoton with $\$ 325,472$, fraudulent act by the Ghana youth and employment agency, the questionable contract by SUBAH for IT consultancy, RLG, DKM and so on. Every corporate entity in Ghana has paid significant fines during the past decade for phony accounting, outright embezzlement by CEOs, securities fraud. As projected in 2016 report to the nations by Association of Certificated Fraud Examiners (ACFE), a typical organization loses $5 \%$ of its annual revenue to fraud. Ghana has been ranked $84^{\text {th }}$ of corruption in the world and $16^{\text {th }}$ in Africa according to the Transparency international corruption perception index. The financial sectors are experiencing an increment fraud cases (KPMG, 2012). The total monetary value involved in all reported fraud cases in corporate financial institutions both attempted for the fiscal year 2016-2017 amounted to approximately GH\$244.32m according to the bank of Ghana.

The Ghanaian financial institutions has noticed expanding blooming in the last decade, a development that has not been without it peril or risk, Incidence of fraud has also been on rise. Ghanaian Financial institutions has experienced and lost huge sums of money and both parties are affected when figures are revealed. The fraudulent act takes the form of embezzlement, misappropriation of funds, aiding, abetting, and card fraud, making false entries in books or making false statement in credit applications, money laundering and other fraudulent practices. (Cordis and Lambert 2017)

According to the central bank of Ghana, the Bank of Ghana (BOG) revealed that, the rising spate of card fraud and defalcation especially in the financial institution is threating the integrity of the financial system in Ghana. Data from the financial intelligence indicated that attempts to cash more than GH\$923,883.86million from the banks using 26 cloned cheques were attempted in the year 2016. (Bank of Ghana intelligence Report, 2016) The effects of all these are not minimal, instead may cause corporate entities failure and distress, thus may embodiment one of the major factor of bankruptcy in the globe (Iceland crisis, 2008). In fact, fraud in financial institutions has caused damage to subordinates morale, brand, reputation and business. (Chen, Zhu et al. 2011). It can lead to a closure of an organization. In view of the harms brought by corporate fraud, the current study focuses on the perception of 


\section{MInstitute ${ }^{\text {Mink }}$}

International Journal of Accounting and Financial Reporting

ISSN 2162-3082

2018, Vol. 8, No. 3

Accountants in corporate financial Organizations within Ghana on the fool effective measures used to detect and prevent corporate fraud.

In addition, Rezaee (2005) as cited by Frimpong et al, 2017 reiterated that financial fraudulent report in recent times has been quite unprecedented. Auditors are mandated for detecting fraud, authorized to audit all financial transactions and have the power and the duty to report any wrong doing committed by individuals which is contrary to the audit rules. These fraudulent acts have shown how the existing and well- known prevention and detecting methods and auditing failures have resulted in corporate failures, demolishing the confidence of investor, and preventing people from investment. (Xu, Zhang et al. 2017) The effects on fraudulent acts are not small, instead may cause entities failure and distress. As at now, there are no prior studies done regarding accountant perception on effectiveness of corporate fraud detection and prevention methods especially in Ghana.

In spite of corporate organizations actively to be brought down the incidence of fraud, it is imperative to note that the effectiveness of the prevalent fraud executing controls are not demolished. The growth in corporate financial institutions fraud cases calls for critical examination of the level of effectiveness of corporate fraud prevention and detection methods in Ghana with the perception of Accountants who are stewards and important figure for corporate organizations. Thus, the purpose of this study is to analyze and comprehend Accountants perceptions regarding the numerous types of prevention techniques and the empiricism on the fraud incidence in the organization. However, Management can shed lights on whether to improve organization anti- fraud policies or envisaged organizational fraud methods as well as external and internal auditors, investors, management, fraud examiners will benefit from this study findings, when considering the effectiveness of the detection and prevention methods.

The remainder of this paper is organized as follows. Section two presents Literature Review concerning and addressing fraud prevention and detection technique. Section three talks about the effective fraud prevention methods. Section four highlights research methodology. Section 4 reports the results of the main tests and the additional test. The final section draws the final conclusion.

\section{Literature Review}

Investors in companies are victims of fraudulent especially investors in initial Public offerings (IPO) since wealth flows directly from investors to the company and become available for the use of manipulation of management. (Petraşcu and Tieanu 2014) In today's business world, detection and prevention methods in relation to corporate fraud are a necessity. Therefore, billions of monies lost and risk can be reduced through an effective prevention and detection measures. Companies without effective detection and prevention methods experienced loss approximately $45 \%$ greater than those with effective prevention, deterrence and detection methods. (Association of Chattered Fraud Examiner, 2012 as cited by Mohammed et. all, 2016). 
With this, it is very imperative for organizations to implement fraud prevention and detection mechanism effectively. The effectiveness of prevention and detection methods could persuade individuals that they should not detriment the organization because of the increased probability of prevention, detection and the punishment as well. (Zhou, Zhang et al. 2018) Companies specifically mitigate fraudulent acts by instating two important policies namely deterring potential fraud with strong ethical tone at the top and strict fraud management programme (CAQ, 2010) and by detecting the activities that have occurred. However, whistleblower as detector always detect at the presence and at the same may help detect fraud incidence.(Othman, Aris et al. 2015) There are enormous corporate fraud prevention and detection methods which may be used to bring down the detriment associated with organizations. Fraud is immune, very tedious to tackle, detect and prevent especially in today's technological era, thus the most effective methods utilized in dealing with fraudulent acts must also be implemented. (Purnamasari and Amaliah 2015)

\subsection{Effective Fraud Prevention Methods}

Maintaining Fraud policy and training: organizations should create; maintain fraud policy and training for guiding employees. The development and execution of rigorous fraud control policy for most organization is crucial step towards effective fraud combating. Employees can only comply with policies if is vividly set out in a comprehensive document which details methods to be followed. It is tedious to prove that one has committed a scandal where no such policy documents exist. Indeed the lack of clear guidelines is often the first excuse offenders will use when questioned concerning fraudulent acts. Therefore, various avenues of information include use in orientation of new hires, employee training seminars, and annual performance evaluation. The policy document should also set out other matters such as the responsibility for fraud control, employment screening, a fraud awareness program, risk assessment program, and the consequences of fraudulent action and/or withholding information concerning any such action.

Employees Background Checks: According to Price Waterhouse Coopers survey in 2007 identified that approximately $71.4 \%$ of all fraud was committed by inside or internal perpetrators. It is very crucial for every organization to check and screen employees and it is the first line of defense against fraud. It is only in the few years that many organizations have come to appreciate its significance. The pre-employment screening and background checking has been included in the Australian standard on fraud and corruption control. In recent years, many fraud cases have been disseminated which adequately signaled that proper screening is not sumptuousness option. Most fraudulent acts could have averted if fool proof employees screening and background have been carried out. It is a fact that, to reduce exposure to combating fraudulent activity, organizations should clearly defined pre-employment standards which must be satisfied.

Accounts Reconciliation: Most studies done by researchers revealed that, several fraudulent acts are committed by perpetrators inside the organizations including accountants, auditors and management. All accounts reconciliations and general ledger balances should have an independent review by individual outside the duty areas such as Accountant, Auditors, 
investors and analyst. This allows for better reviews, ensuring nothing is flawed and providing a comprehensive deterrent for fraudulent activities.

Anonymous hot lines: According to Holtfreter (2004), anonymous hot lines have become a great approach in combating fraud. The anonymous reporting mechanism such as fraud hot line is very effective means of detecting occupational fraud. Employees are able to gives confidential internal information without been panic as a result of being a whistleblower (pergola and Sprung, 2005). The anonymous hot lines is not just recognized as detection tool but it is also enhances deterrence. (Biers taker et. al, 2006) Potential perpetrators will likely consider risk of been found and they have second thought.

Annual Auditing: Organizations victimized with fraudulent acts is as result of failure to conducting annual audits. Annual auditing should be conducted to encourage all book keeping-related workforces to keep things honest because they can never be sure what questions an auditor is going to ask or what documents an auditor may request to review. However, independent checks on performance, using audits, surprise checks ups, inventory counts and other procedures to verify compliance with procedures as well as accuracy.

Use of Analytical Review: Analytical review tools which an accountant or analyst may use such as budget comparisons, making comparisons with industry averages, review of general ledger, journal entries, ratio analysis, and trend analysis. These may behoove the accountant, analyst, investigator and auditors to analyze numerous years of financial statement data using different techniques to obtain a vivid picture of financial implications of any fraudulent scheme. In fact, frauds have a great effect on financial position trends and ratios in organizations. Accounts that are falsified to conceal a fraud may manifest unusual relationships with other accounts that are not manipulated.

Segregation of Duties of Employees: Segregation or assigning employees should be implemented so that one employee doesn't have much control over an area or duty. Separate accounting and account payables functions in an institution. Every payroll should be checked and reviewed personally by managers and owners. The person who has custody of the checks should never have check signing authority. The person opening the mail should not record the receivables and reconcile the accounts, the one who control and first receives the bank statement and other sensitive documents. All functions should be separated or segregated for employees in the organizations and it is an effective method of combating fraud.

Forensic Accountant: corporate fraud such as Enron, WorldCom, etc. has shaken the world. These fraudulent damages challenged the instituted systems and these are an indicator of changing ways of committing fraud in corporate sectors in an economy. Various and more stringent measures, rules, and regulations are been instituted but who has the expertise to execute these rules. When something goes wrong who has the expertise to investigate it, thus update systems continuously when system are out of date. Rules and regulations will not work without human intervention but who has the requisite knowledge and capability of intervening. These call for forensic Accountant. Forensic Accounting is the utilization of accounting skills to investigate fraud and analyze financial transactions and organizations settings to obtain the truth and develop an expert opinion relating possible scandal acts. 


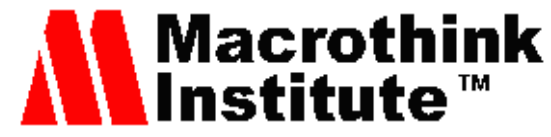

International Journal of Accounting and Financial Reporting

ISSN 2162-3082

2018, Vol. 8, No. 3

Forensic Accountants performs litigation support, and investigative or fraud accounting. Forensic accountant's litigation support includes business assessment, revenue analysis, expert witness testimony and future earnings estimate. Forensic Accountant does investigating as of gathering evidence of criminal conduct, and substantiating damages (Nunn et al. 2006). It is emerged as a significant discipline in accounting which can be of great importance for corporate entities especially the financial entities in Ghana, and the world at large though the approach seems to be new discipline:

\section{Methodology}

The research is a quantitative approach to examine critically the effectiveness of fraud prevention and detection methods. In this study, the sample comprises Accountant, Auditors, investors, management and fraud investigators from selected financial Organizations in Ghana. The respondent was randomly selected from both public and private financial institutions.

A structured survey questionnaire was utilized to assisting the collection of information from the targeted respondents. The questionnaire on the study was tested before it was administered. (Idolor, 2010) With this, professional Auditors and Accountants from different organizations evaluated the questionnaires for quality assurance of the significant measurement of the objectives of the study, thus irrelevant items were dismissed before it was administered.

The questionnaire is made up of 35 questions which were divided into three sections. Section A consist of the profile of the Respondent (5), sections two contains 20 questions to the respondent on the effectiveness of corporate fraud detection and Prevention Methods and finally, the third Section contains 10 questions concerning the effectiveness of technology software to detect and prevent fraud. A four point Likert scale ranging from "1" (very Effective) to range "4" (not very effective) was used on the effectiveness of fraud detection and prevention methods. A total of two hundred (200) questionnaires were distributed to the selected public and private financial institutions from which one hundred and fifty (150) were returned. The distributing was done through hand delivery, by email and the personal collection.

\subsection{Study Participants}

The participant for the study is made of 70 accountants and Auditors from the selected financial institutions in Ghana. With the usage responses of the 70, approximately 50 percent were had through mail which was sent to Field Accountant in Ghana which the rest were obtained from individuals

Seventy- two (72) percent of the respondents are males, and the twenty-eight percent are females. Thirty -three percent of the respondent hold Bachelor's degree, fifty-two (52) percent have master's degree and five percent of them have Doctor of Philosophy (PHD). Fifteen percent of the participants were holding ACCA certificate, thirty-two of the participant are certified Management Accountant (CIMA), and Forty-five of the participants were certified chattered Accountants in Ghana (ICAG), four (4) of the participant are 


\section{Macrothink}

International Journal of Accounting and Financial Reporting

ISSN 2162-3082 2018, Vol. 8, No. 3

certified Public Accountants (CPA). The remaining participants did not provide their certification. All the participants work in the selected Financial Institutions in Ghana. Summary of these findings are shown below in table 1

Table 1. Respondent demographic information

\begin{tabular}{lll}
\hline Participant Education & percentage & Number \\
\hline Bachelor's Degree & 33 & 23 \\
Master's Degree & 52 & 36 \\
PHD & 15 & 11 \\
Certification & & \\
\hline ACCA & 15 & 11 \\
CIMA & 32 & 23 \\
ICAG & 45 & 32 \\
CPA & 4 & 3 \\
\hline
\end{tabular}

\section{Results and Findings}

Effectiveness of Fraud Prevention and Technology Software

Based on the questionnaires administered to the targeted sample, Auditors and Accountants were asked to indicate and rate the effectiveness of the following fraud detection and prevention methods and Software: corporate code of conduct, internal control review, employees background, Bank Reconciliation, Fraud hotline, Annual Auditing, Use of Analytical Review, Segregation of employees duties, Use of Forensic Accountant, Whistle blowing policy, Fraud prevention and detection training, Operational Audits, Ethics Training, fraud vulnerability, Employee Counselling programs, Cash Review, password protection, Discovery sampling, Data mining, Digital analysis, Continuous Auditing, Firewalls, and Filtering software on the Likert scale 1(not very effective) to Likert scale 4 (very effective). In addition, Auditors, Accountants were asked on the use of fraud detection and prevention methods in their organization and how the existing fraud and detection methods work in reducing fraud. 


\section{Ml Macrothink}

International Journal of Accounting and Financial Reporting

ISSN 2162-3082

2018, Vol. 8, No. 3

Table 2. Effectiveness of fraud prevention and detection methods and percentages of accountants and auditors who use these methods

\begin{tabular}{|c|c|c|c|}
\hline Prevention and Detection Methods & Percentages & Mean & SD \\
\hline Corporate code of conducts/ ethics policy & 94 & $3.8(5)$ & .462 \\
\hline Internal control Review and improvement & 92 & $3.9(4)$ & .610 \\
\hline Employees background checkup & 89 & $2.3(14)$ & .672 \\
\hline Bank Reconciliation & 86 & $2.5(12)$ & .384 \\
\hline Fraud hotline & 85 & $2.1(16)$ & 1.040 \\
\hline Annual Auditing & 82 & $4.5(2)$ & 1.904 \\
\hline Use of Analytical Review & 80 & $3.6(7)$ & .230 \\
\hline Segregation of employees duties & 79 & $3.7(6)$ & .336 \\
\hline Use of Forensic Accountant & 78 & $3.5(8)$ & .144 \\
\hline Whistle blowing policy & 75 & $4.0(3)$ & .774 \\
\hline Fraud prevention and detection training & 70 & $3.2(10)$ & .034 \\
\hline Operational Audits & 70 & $3.3(9)$ & .032 \\
\hline Ethics training & 67 & $2.4(13)$ & .518 \\
\hline Fraud vulnerability & 62 & $2.2(15)$ & .846 \\
\hline Employee Counselling programs & 58 & $2.7(11)$ & .176 \\
\hline Cash Review & 56 & $5.2(1)$ & 4.326 \\
\hline
\end{tabular}

As shown in Table 2, from the statistics analysis, cash review accounted as the most effective prevention and detection methods with a mean of (mean 5.2) been the highest rating. It is followed by Annual Auditing (mean 4.5), whistle blowing policy with a mean of (4.0), internal control review and improvement, ( mean 3.9), corporate code of conducts/ ethics policy (mean 3.8), segregation of employees Duties, (mean 3.7), organizational use of Forensic Accountant with a mean (mean 3.5). Fraud prevention and detection training (mean 


\section{$\triangle 1$ Macrothink}

International Journal of Accounting and Financial Reporting

ISSN 2162-3082

3.2) and the least prevention and detection method to curb the incidence of fraud is fraud hotline.

Table 3. Effective fraud technology and software and percentages of it usage by accountants and auditors

\begin{tabular}{llll}
\hline Fraud Technology methods & Percentages & Mean & SD \\
\hline Password Protection & 58 & $3.6(1)$ & .230 \\
Discovering Sampling & 61 & $2.3(5)$ & .672 \\
Data Mining & 65 & $3.5(2)$ & .144 \\
Digital Analysis & 67 & $3.4(3)$ & .078 \\
Continuous Auditing & 70 & $2.1(7)$ & 1.040 \\
Firewalls & 71 & $2.2(6)$ & .846 \\
Filtering Software & 72 & $2.4(4)$ & .518 \\
\hline
\end{tabular}

Under the fraud technology prevention methods, Password protection were perceived as the most effective prevention and detection methods with the highest mean rating. It is interesting to note that organizational use of password protection was the least often used method to prevent fraud (58 percent), but received the highest rating of effectiveness ( mean 3.6). This is followed by Data Mining (Mean 3.5) and Digital Analysis with effective rating (mean 3.4) respectively. The rest of the methods have below the mean (3.4) but the least methods to combat fraud are filtering software which was mostly used.

It is clear from the findings that, respondent perceived cash review as the most effective tool to prevent fraudulent act in Organizations. In reviewing cash on regular basis, will help to ensure the amount of cash that comes in and amount of money that goes out in order to prevent stolen cash. In comparison with Abdul et al (2014) which rated Cash review as the fifth most effective tool perceived by respondents and (Bierstaker et al., 2006) which also rated cash review in his studies as nineteen $\left(19^{\text {th }}\right)$ most effective technique perceived by the respondent in curbing fraudulent act.

However, fraud hotline is the least prevention method perceived by the respondent that is associated with some reasons with which one is the cost involves in using the hotline. Fraud hotlines provide room for staff to report unethical acts among employees. Therefore Financial organizations should consider providing hotlines which would provide secure way of admitting information's as it is naturally anonymous. Meanwhile, effective fraud technology software like password was perceived by the respondent as the most effective in curbing fraud which has to be installed in the computer based on the findings. 


\section{Conclusion}

The study investigated the perceptions of Accountants and Auditors on the use and effectiveness of fraud detection and prevention methods among selected financial institutions in Ghana. The results revealed that, organizational quietly utilized data mining, digital analysis, internal Control and improvement and fraud prevention and detection training in combating fraud. However, the findings further revealed that, organizational use of password protection, Cash Review, Annual Auditing, Whistle blowing policy were less often utilized even though having the highest rating of effectiveness. In particular, organizational use of cash review was the least often used method but had the highest rate of effectiveness.

Fraud is immune regardless of the size of the organizations and all the efforts of management trying hard to mount fool proof prevention and detection methods to bring it to the bearest minimum. With this, awareness has to be created among individuals especially employees on the activities that can emerge fraud, thus the consequence of it on the organization and the solutions in combating it. The study has practical effects for accountants, Auditors on what fraud detection and prevention methods work best as well as the most effective prevention methods not used.

Therefore, Accountants and Auditors in financial institutions can rely on and implement all those effective preventive and detective methods as discussed in this paper. The study would mostly recommend that Accountants, Auditors and management use the most effective prevention and detection methods like Cash Review, Annual Auditing, whistle blowing and installation of Password protection on computers in order to prevent costly frauds in their organizations based on the findings. Different types of fraud accounts for methods to deal with, therefore Accounting practitioners, Auditors and management have to consider investing in the less often used methods based on the findings especially Cash Review, Annual Auditing, whistle blowing and organizational use of Forensic Accountant.

Future study could explore using both qualitative and quantitative approach to gather data on the reasons why organizations are reluctant to invest on less often detection and prevention methods especially organizational use of cash Review. In addition, future research may also consider exploring the role of detecting, and preventing fraud should be differentiated in an organization setting using both quantitative and qualitative approach.

\section{Acknowledgement}

The authors would like to express their gratitude to Adu Amankwaah Isaac, school of management, Jiangsu University and the Faculty of Corporate finance, Jiangsu University for providing financial assistance and facilities for the study. The article would not have been possible without their support.

\section{References}

ACFE US. (2017). ACFE Occupational Fraud Report to Nations Survey.

Albrecht, W. S., \& Albrecht, C. C. (2002, April). Root out financial deception: detect and eliminate fraud or suffer the consequences. Journal of Accountancy, 30-34. 
Bank of Ghana. (2016). Intelligence Report of fraud on Financial Institutions, Ghana.

Bierstaker, J. L., Brody, R. G., \& Pacini, C. (2006). Accountants' perceptions regarding fraud detection and prevention methods. Managerial Auditing Journal, 21(5), 520-535.

Chen, Y., et al. (2011). Corporate fraud and bank loans: Evidence from china. China Journal of Accounting Research, 4(3), 155-165.

Cordis, A. S., \& Lambert, E. M. (2017). Whistleblower laws and corporate fraud: Evidence from the United States. Accounting Forum, 41(4), 289-299.

Gullkvist, B., \& Jokipii, A. (2013). Perceived importance of red flags across fraud types. Critical Perspective on Accounting, 24, 44-61

Hajek, P., \& Henriques, R. (2017). Mining corporate annual reports for intelligent detection of financial statement fraud - A comparative study of machine learning methods. Knowledge-Based Systems, 128, 139-152.

KPMG Fraud. (2012). Bribery and Corruption Survey. Retrieved from http://www.kpmg.com/au/en/issuesandinsights/articlespublications/fraudsurvey/pages/fraud-b ribery-corruption-survey-2012.aspx

KPMG. (2013). KPMG Malaysia Fraud, Bribery and Corruption Survey, Malaysia.

NFA. (2014). National Fraud Annual Report, UK. Retrieved from https://www.gov.uk/government/publications/national-fraud-authority-annual-report-and-acc ounts-2013-to-2014

Othman, R., et al. (2015). Fraud Detection and Prevention Methods in the Malaysian Public Sector: Accountants' and Internal Auditors' Perceptions. Procedia Economics and Finance, $28,59-67$.

Peterson, B. K., \& Buckhoff, T. A. (2004). Anti-fraud education in academia. Advances in Accounting Education: Teaching and Curriculum Innovations, 6, 45-67.

Petraşcu, D., \& Tieanu, A. (2014). The Role of Internal Audit in Fraud Prevention and Detection. Procedia Economics and Finance, 16, 489-497.

Purnamasari, P., \& Amaliah, I. (2015). Fraud Prevention: Relevance to Religiosity and Spirituality in the Workplace. Procedia - Social and Behavioral Sciences, 211, 827-835.

PwC. (2012). Fighting Fraud in the Public Sector II. Retrieved from http://www.pwc.com.au/consulting/assets/risk-controls/Fighting-Fraud

PwC. (2014). Fighting Fraud in the Public Sector III. Retrieved from http://www.pwc.com.au/consulting/assets/risk-controls/Fighting-FraudFeb15pdf

Rezaee, Z., Crumbley, D. L., \& Elmore, R. C. (2004). Forensic accounting education. Advances in Accounting Education: Teaching and Curriculum Innovations, 6, 193-231. 


\section{Macrothink}

International Journal of Accounting and Financial Reporting ISSN 2162-3082 2018, Vol. 8, No. 3

Rezaee, Z., Crumbley, D. L., \& Elmore, R. C. (2004). Forensic accounting education. Advances in Accounting Education: Teaching and Curriculum Innovations, 6, 193-231.

Smith, G. S. (2012). Can an auditor ever be a first responder to financial frauds? Journal of Financial Crime, 19(3), 291-304.

Wells, J. T. (2003, March). Protect small business. Journal of Accountancy, 26-32.

$\mathrm{Xu}$, Y., et al. (2017). Board age and corporate financial fraud: An interactionist view. Long Range Planning.

Yang, D., et al. (2017). The determinants of financial fraud in Chinese firms: Does corporate governance as an institutional innovation matter? Technological Forecasting and Social Change, 125, 309-320.

Zhou, F., et al. (2018). Delisting pressure, executive compensation, and corporate fraud: Evidence from China. Pacific-Basin Finance Journal, 48, 17-34.

\section{Note}

Respondent working experience was not correlated with the results of interest

\section{Copyright Disclaimer}

Copyright for this article is retained by the author(s), with first publication rights granted to the journal.

This is an open-access article distributed under the terms and conditions of the Creative Commons Attribution license (http://creativecommons.org/licenses/by/4.0/) 